\title{
Reviewing the effect of the stretch-shortening cycle workouts on shot hit performance
}

Demirci Deniz $^{1 \mathrm{AB}}$, Konyali Mustafa ${ }^{2 \mathrm{AB}}$, Akdeniz Hakan ${ }^{3 \mathrm{CD}}$, Sekban Gülşah $^{4 \mathrm{DE}}$, Aydin Mensure ${ }^{5 \mathrm{DE}}$

${ }^{1}$ Faculty of Health Sciences, Department of Ergoteraphy, Istanbul Bilgi University, Turkey

${ }^{2}$ The Institute of Health Sciences, Faculty of Sports Sciences, Kocaeli University, Turkey

${ }^{3}$ The Institute of Health Sciences, Department of Physical Education and Sports Teaching, Sakarya University, Turkey

${ }^{4}$ Faculty of Sports Sciences, Department of Physical Education and Sports Teaching, Kocaeli University, Turkey

${ }^{5}$ Faculty of Sports Sciences, Department of Recreation, Kocaeli University, Turkey

Authors' Contribution: A - Study design; B - Data collection; C - Statistical analysis; D - Manuscript Preparation; E - Funds Collection.

\begin{abstract}
Purpose: $\quad$ The purpose of this study was to determine the effect of the stretch-shortening workouts for male football players between the ages of 18 and 20 on shot hit performance.

Material: $\quad$ A pretest-posttest trial method with the control group was used in the research. Sixteen male footballers between the ages of 18 and 20 voluntarily participated in our survey. The footballers were divided into two groups by the random method, and thus the experimental group ( 8 footballers) and control group ( 8 footballers) were constituted. The pretest values of the experimental and control groups were recorded by applying the Dewitt-Dugan shot hit test before eight weeks of training. The experimental group performed technical-tactical training with stretch-shortening cycle workouts for 90 minutes three days a week, while the control group solely performed technical-tactical training for 90 minutes three days a week. Both groups were tested after the eight-week training program to obtain the final test values. Two measurements each were taken from the athletes, and the evaluation considered the best data SPSS 21 packaged software calculated the descriptive statistics of the data collected; these data were analyzed by Mann Whitney-U, and Wilcoxon Signed tests. Statistically, significance degree was set at $(p<0.05)$ level.

Results: $\quad$ The results of the experimental and control group were respectively found as $p=0.01$ and the significant difference $(p<0.05)$ was found in the comparisons of in-group and posttest. The statistical values obtained in intergroup comparisons were found as $p=0.75$ for the first test and $p=0.48$ for the last test. There was no significant difference $(p>0.05)$.

Conclusions: In conclusion, while there is an effect of the stretch-shortening workouts on the shot hit performance of in-group athletes before eight weeks of technical-tactical football training, there is no significant difference between the groups. Stretch-shortening cycle workouts can be suggested as an addition to the training of the athletes before technical-tactical football training.

Keywords: football, hit, stretch-shortening, shot
\end{abstract}

\section{Introduction}

Sport is an essential part of the modern human life and also one of the most beneficial social aspects that positively affect societies [1]. One branch of sport, football, attracts great attention and generates international excitement, contributing to tourism and the presentation of the countries within the code, uniting people across the globe [2]. Plyometric training is performed to increase the efficiency of the athlete in sports like football that necessitate frequent turning and twisting [3].

In plyometric workouts, concentric muscular contraction follows the eccentric muscular contraction during movements such as running, walking and jumping. This natural combination of the muscle is called a 'stretchshortening cycle' (SSC) and referred to as the stretch reflex in the literature [4]. Plyometric training is mostly called 'elastic force training' 'reactive training' and 'eccentric training' and is divided into sub-classes like 'depth jump' and the 'strike method. A plyometric workout allows the muscle to reach maximal force as early as possible [5]. The purpose of these workouts is mostly related to elastic force and to provide expeditious application of a high amount of force within a short time by the concentric contraction after the eccentric contraction of the muscle. Thus, the elastic force arises by an excellent speed contraction and overcoming of resistance due to the musculo-nervous (c) Demirci Deniz, Konyali Mustafa, Akdeniz Hakan,

Sekban Gülşah, Aydin Mensure, 2018

doi:10.15561/20755279.2018.0103 system. This training is a type of positive, negative force workout and it aims to use rapid force and also develop explosive jumping [6, 7].

It is stressed that plyometric training has advantages and disadvantages on sport performance. It provides an advantage by speedy and explicit maximal force enhancement without any increase in body weight or any change in muscle mass due to being supported by the intramuscular coordination arising from the high load intensity. It should not be applied to children, beginners at the gym and young adults because extra strength and a well-prepared musculo-skeletal system are required. Plyometric workouts without following the rules may have possibilities of injury [8]. Plyometric training in young athletes should be progressed from easy to difficult. The sets applied ought not to be shorter than 6-8 seconds; and factors like the intensity, volume, frequency, and recovery should be considered when preparing plyometric training for young people [9].

We can see when looking at literature surveys that the motoric characteristics are based on the effects of the plyometric (stretch-shortening) cycle [7, 10]. Our study aims to determine whether the stretch-shortening cycle workouts have any effect on the shot hit performance of footballers.

\section{Material and methods}

Participants 
Sixteen male footballers who play in the same team in the amateur league voluntarily participated in this study.

The participants' average age was $18.93 \pm 0.77$ year; height average was $170.87 \pm 8.14 \mathrm{~cm}$, bodyweight average was $66.55 \pm 7.16 \mathrm{~kg}$, sports experience average was $2.81 \pm 0.75$ years.

This survey was carried out using the simple random sampling method in the pretest-posttest trial model with a control group [11].

For the survey, 11/9 decision numbered, 2014/147 project numbered, 13,05,2104 dated Clinical Investigation Ethics Committee Report was taken.

Procedure

Pretest measurements of the Dewitt-Dugan shot test were received from 16 male footballers before the training. Each of the athletes took two test values, and the best value was accepted. The athletes were divided into two groups (experimental and control) after the measurement. Experimental and control groups performed training programs taking 90 minutes a day, three days a week, for a total of eight weeks. The experimental group athletes performed stretch-shortening cycle workouts and technical-tactical training while the control group athletes just performed the technical and tactical training. Both groups of athletes' posttest measurements of the Dewitt-Dugan shot test were recorded at the end of the eight-week training program. The data obtained were statistically evaluated.

Training Program of the Experimental and Control Groups

Two different training programs for 90 minutes were performed by athletes on non-successive days.

Experimental Group

The athletes performed 27-30 minutes stretchshortening cycle workouts between $80 \%-85 \%$ intensity interval (information on the content of the training for five minutes, warm up running for 15 minutes, stretching for 10 minutes, totaling 24 units of training).

One Unit Training of Experimental Group

Training Purpose: Stretch-shortening cycle workouts. Training Time: 90min.

Table 1: Stretch-Shortening Cycle
Training Age Group: 18-20.

\section{Control Group}

After undertaking 30-minute preparation workouts, 50 minutes of technical-tactical training at $76 \%$ intensity were performed by the attendees. The training was concluded by 10 minutes of jogging-stretching workouts after the technical-tactical training.

One Unit Training of Control Group.

Training Purpose: Technical/Tactical.

Training Time: $90 \mathrm{~min}$.

Training Age Group: 18-20.

Explanation of Training: 5 min.

Explanation of Training and Warmup Running: 25 minutes.

Stretching and Cooling Down Running: 10 minutes.

Basic Part of the Training: 50 minutes.

1st workout: 2:1, 2:2, 2:1 A free game was played on the condition that each of the players stands in his own area. The game was stopped by the trainer, and it was checked whether the players had violated the area or not. The players were warned on this issue. Points to consider: To create a free field and to be able to use it, support, quality pass, intrusion, creativity.

2nd workout: After the application was well understood, the workout continued as a competition by considering the points and removing the signs.

Measurement of Dewitt-Dugan Shot Test

The target seen in Figure 1 was drawn on a board. The attendees shot the ball five times from 27 meters away from the board. The scores that hit the target were recorded. The scores that hit the line were counted into the higher scored area. The values obtained were set as the scores. The missed shots were not included in the survey.

Statistical analysis

SPSS 21 packaged software analyzed the data. The Wilcoxon Signed Ranks test measured the in-group, and the Dewitt-Dugan shot hit test was performed pretest, and posttest. Between-groups, pretest, and posttest values were analyzed by the Mann-Whitney $U$ test and a $p<0.05$ significance level was sought.

\begin{tabular}{|c|c|c|c|c|c|}
\hline Line & Training Method & Intensity & Repetition & Set-relaxing & Total (min.) \\
\hline A) & \multicolumn{5}{|l|}{ Preparation Stage } \\
\hline 1 & \multicolumn{4}{|c|}{ Explanation of Training } & $5 \mathrm{~min}$. \\
\hline 2 & \multicolumn{4}{|l|}{ Warm-up } & $15 \mathrm{~min}$. \\
\hline 3 & \multicolumn{4}{|l|}{ Stretching } & $10 \mathrm{~min}$. \\
\hline B) & \multicolumn{5}{|c|}{ Stretch-Shortening Cycle } \\
\hline 1 & S.T.A.A.S.H.F.T & $80 \%$ & 25 & 660(Sec.) & $9 \mathrm{~min}$. \\
\hline 2 & S.T.Ç.K & $85 \%$ & 20 & 660(Sec.) & $9 \mathrm{~min}$. \\
\hline 3 & A.S.T.i & $80 \%$ & 25 & 660(Sec.) & $9 \mathrm{~min}$. \\
\hline C) & \multicolumn{4}{|c|}{ Normal Team Training (Technical-Tactical) } & $25 \mathrm{~min}$. \\
\hline D) & \multicolumn{4}{|c|}{ Cooling down (Jogging-Stretching) } & $8 \mathrm{~min}$. \\
\hline
\end{tabular}




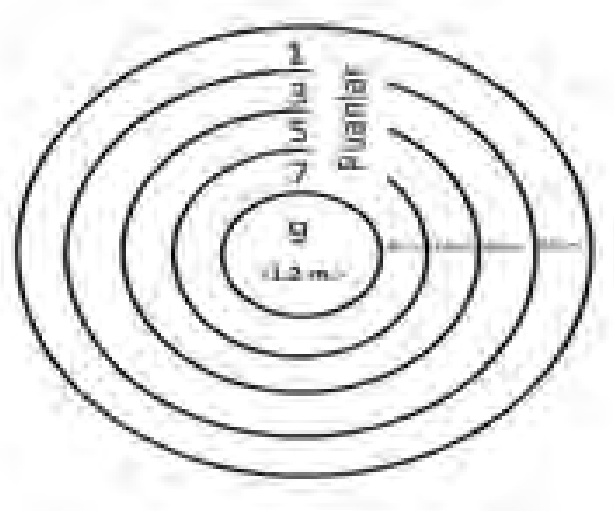

Figure 1. Dewitt-Dugan Board Measurements [12]

\section{Results}

As is in Table 1, the average age of the experimental group athletes was $18.87 \pm 0.83$ years, height average was $168.87 \pm 7.80 \mathrm{~cm}$, bodyweight average was $64.97 \pm 7.26$ $\mathrm{kg}$, sports age average was $2.75 \pm 0.70$ years. On the other hand, the average age of the control group athletes was $19 \pm 0.75$ years, height average was $172.87 \pm 8,49$ $\mathrm{cm}$, bodyweight average was $68.12 \pm 7.17 \mathrm{~kg}$, sports age average was $2.87 \pm 0.80$ years.

As is seen in Table 2, a significant difference smaller than $\mathrm{p}<0.05$ was found when the Dewitt-Dugan shot tests of the control group athletes were compared. A significant difference smaller than $\mathrm{p}<0.05$ was also found when the Dewitt-Dugan shot hit tests of the experimental group of athletes were compared.

As is seen in Table 3, there is no significant difference, the $\mathrm{p}$ values of all the tests are $\mathrm{p}>0.05$

\section{Discussion}

This paper researches the effect of stretch-shortening cycle workouts performed by amateur male footballers between 18 and 20 years of age on shot hit performance. Orhan et al. [13] conducted a survey called 'the effect of rope and weight rope workouts on basketball skills.' In their investigation, the experimental groups performed rope and weighted rope workouts; while the control group performed only the technical training. At the end of the

Table 2. Anthropometric descriptive statistics of experimental and control group athletes

\begin{tabular}{llllll}
\hline EXPERIMENTAL & N & Min. & Max. & Mean & Standard Deviation \\
\hline AGE (year) & 8 & 18.00 & 20.00 & 18.87 & 0.83 \\
WEIGHT (kg) & 8 & 56.30 & 76.10 & 64.97 & 7.26 \\
HEIGHT (cm) & 8 & 160.00 & 181.00 & 168.87 & 7.80 \\
SPORT AGE (year) & 8 & 2.00 & 4.00 & 2.75 & 0.70 \\
CONTROL & N & Min. & Max. & Mean & Standard Deviation \\
AGE (year) & 8 & 18.00 & 20.00 & 19 & 0.75 \\
WEIGHT (kg) & 8 & 59.10 & 78.40 & 68.12 & 7.17 \\
HEIGHT (cm) & 8 & 160.00 & 184.00 & 172.87 & 8.49 \\
SPORT AGE (year) & 8 & 2.00 & 4.00 & 2.87 & 0.80 \\
\hline
\end{tabular}

Table 3. Comparisons of Wilcoxon Signed Ranks test data of the control and experimental group

\begin{tabular}{llll}
\hline Experimental Group & Pretest Mean. \pm SD & Posttest Mean. \pm SD & $\mathbf{p}$ \\
\hline Dewitt-Dugan Shot TEST & $23 \pm 5.31$ & $28.87 \pm 3.31$ & $0.010^{*}$ \\
Control Group & Pretest Mean. \pm SD & Posttest Mean. \pm SD & $\mathbf{p}$ \\
Dewitt-Dugan Shot TEST & $22.37 \pm 5.37$ & $28.12 \pm 5.05$ & $0.011^{*}$ \\
\hline
\end{tabular}

$*(p<0.05)$

Table 4. Comparison of the test values of Experimental and Control group athletes via Mann Whitney U Test

\begin{tabular}{lc}
\hline Experimental Group and Control Group Tests (mann-whitney u) & $\mathbf{p}$ \\
\hline Dewitt-Dugan Shot Test Pre-measurement & 0.750 \\
Dewitt-Dugan Shot Test Post-measurement & 0.489 \\
\hline
\end{tabular}

$*(p<0.05)$ 
study, a significant difference $(\mathrm{p}<0.01)$ was confirmed in pointed shot number values of the experimental groups before and after the training. On the other hand, there was no significant difference $(p>0.05)$ in pointed shot number values between experimental and control groups. In the research done, no statistically significant difference is confirmed when the last measurements of the DewittDugan shot test are compared after the training performed by the athletes of the experimental and control groups $(\mathrm{p}=0,489)$

Özbek [14] conducted research to review the effect of preparation period and upper extremity force workouts on the shot hit of male basketball players between the ages of 15 and 17 . He determined a significant difference $(p<0.01)$ in shot hit values of quick power training performed with jumping and sprint workouts. Also, in this survey, the value is accepted as $p=0.01$, and the significant difference is also confirmed in the pretest and posttest measurements of control group athletes in the Dewitt-Dugan shot test $(p<0.05)$. These two surveys verify each other regarding the effect of the training performed because both athlete groups applied the training program which can develop quick power and affect the shot hit performance.

Kurban's [15] research, 'Reviewing the effect of football training on the technical progress of boys between 10-13 ages' shows the positive effect of the football training on the shot hit performance $(\mathrm{p}<0.05)$. Kurban asked the participants to undertake some technical workouts like inside cut, shot, dribble, and jink. Then, a significant difference in the shot hit performance was observed. In this same study, the control group of athletes performed similar training and a significant difference $(p<0.05)$ was found when the pretest and posttest measurements of the Dewitt-Dugan shot test of the athletes were compared $(p=0,01)$. It may be thought that the technical training affects the shot hit values positively.

Ölçücü [16] researched the effect of plyometric training on the strengthening of arms and legs, service, forehand, backhand, striking velocity, and the percentage of hits for male tennis players whose age average was $22.10 \pm 1.33$. In this study, the experimental group performed the plyometric workout in addition to classical tennis training; the control group only completed the classical tennis training. At the end of the research, the plyometric training positively affected the backhand, cross and service hit of the athletes.

Canikli [17] actualized a study to analyze the effect of plyometric training on backhand and forehand, striking velocity and hit percentages of male university students who play tennis. While the experimental group performed plyometric training in addition to the classical tennis training, the control group solely carried out the classical tennis training. It was determined at the end of the study that the plyometric training affected the backhand, cross and service hit of the athletes positively $(p<0.05)$. The $\mathrm{p}$-value was found as 0.48 in the posttest measurements between groups, and no significant difference $(p>0.05)$ was found at the same time. We can link this different conclusion with the ball being moveable in hit tests performed by the tennis players. Quite the reverse in our research, the footballers hit a dead ball. The number of human subjects was 40 in the surveys of Ölçücü [16] and Canikli [17]. We had only 16 participants. These different participant numbers produced the different results.

In Fletcher and Hartwell's [18] survey called 'The effect of 8 weeks combined weight and plyometric training program on the striking velocity and hit distance for the golfers'. The experimental group performed weight and plyometric training in addition to the normal golf workouts. The control group carried out classical golf training. It was found at the end of the study that the weight and plyometric training program had a positive effect on the performance for hitting the golf ball to the final pit $(p<0.05)$. The $p$-value was found as 0.48 in pretest and posttest measurements between groups. There was no significant difference $(\mathrm{p}>0.05)$. Fletcher and Hartwell conducted plyometric workouts in addition to the golf training. However, the plyometric ones were performed before the technical-tactical ones. There are also studies similar to that of Fletcher and Hartwell. These studies made us think that the plyometric training may be effective on the hit performance. However, the exercise alignments being different may be the reason for the different results.

Eler's [19] study, 'The effect of the strength training particular to handball on some of the performance parameters of young handball players,' was undertaken with 16-year-old male handball players. The experimental group carried out 72 strength and technical training sessions over 12 weeks. The control group solely performed the technical training. They determined statistically significant decrements in technical skills like a shot hit by jumping, and dribbling for 30 meters in the experimental group $(\mathrm{p}<0.05)$. The reasons for the different conclusions are as follows: our research took eight weeks, the number of stretch-shortening cycles and technical workouts was 24 , and thus there was less training over a shorter term.

Ürer [20] examined the effect of plyometric exercises on the upper and lower extremities on vertical jump performance, and upper block hit ratio for male handball players in the 15-17 age group. It was determined that plyometric training has no effect on top block shot performance $(\mathrm{p}>0.05)$. Ürer's survey took six weeks. The athletes performed plyometric exercises before the technical workouts two days a week, besides the normal handball exercises applied five times a week. The greater training frequency may have negatively affected the conclusion.

As a consequence, we observed that the stretchshortening cycle workouts performed before eight weeks technical-tactical training positively affected the shot hit performance of the athletes. Moreover, it can be suggested that this kind of exercise should be performed by elite athletes, different age groups and a bigger sample. As an extra, the hit ratios of the athletes during the DewittDugan shot test can be specified and evaluated as well. 


\section{Conclusions}

As a result, it was found that stretch-shortening cycle training before 8-week technical-tactical soccer training session in athletes significantly improved shot hit performance when compared to athletes who had technical-tactical training session there was no significant difference.

It may be advisable to conduct studies with different age groups and with more subjects.
It may be suggested that the examination the effect of Stretch-Shortening Cycle Workouts on the shot hit performance in elite athletes.

When the Dewitt-Dugan board smash test is being performed, it may be advisable the determination of the percentage of hit points and evaluation in athletes.

The effects of the same work on female soccer players might be examined.

\section{Conflict of interests}

The authors declare that there is no conflict of interests.

\section{References}

1. Sevim Y. Antrenman bilgisi [Training Theory]. Ankara: Nobel Yayınevi; 2007. (In Turkish)

2. Açıkada C, Özkara A, Aşçı A, Turnagöl H, Tınazcı C, Ergen E. Bir futbol takımında sezon öncesi hazırlık antrenmanlarının bir kısım kuvvet ve dayanıklılık özellikleri üzerine etkisi [The effect of pre-season preparatory training on some strength and endurance characteristics of a soccer team]. Hacettepe University Sports Science Journal, 1996; 7(1): 24-32. (In Turkish)

3. Kılıç MN. Futbol takımları altyapı oyuncularına uygulanan pliometrik antrenman programinin fiziksel uygunluk düzeylerine etkileri [Effects of plyometric training program applied to football players in infrastructure teams on physical fitness levels]. [M.Sc thesis]. Atatürk Üniversitesi; 2008. (In Turkish).

4. Konter E. Futbolda süratin teori ve pratiğ [Theory and practice of velocity in football]. Ankara: Bağırgan Yayınevi; 1997. (In Turkish)

5. Anil F, Erol E, Pulur A. Pliometrik çalışmaların 14-16 yaş grubu bayan basketbolcuların bazı fiziksel ve fizyolojik parametreleri üzerine etkisi [The effect of pliometric studies on some physical and physiological parameters of female basketball players aged 14-16 years]. Gazi Üniversitesi Beden Eğitimi ve Spor Bilimleri Dergisi, 2001; 2(6): 19-26. (In Turkish)

6. Arslan Ö. Sekiz haftalik pliometrik antrenman programının 14-16 yaş grubu bayan kısa mesafe koşucularının bazı fiziksel ve fizyolojik parametrelerine etkisi [The effect of the eight-week pliometric training program on some physical and physiological parameters of the female short-range runners in the 14-16 age group]. [M.Sc thesis]. Gazi Üniversitesi; 2004. (In Turkish)

7. Baktaal D. 16-22 yaş bayan voleybolcularda pliometrik çalışmaların dikey sıçrama üzerine etkilerinin belirlenmesi [Determination of the effects of pliometric exercises on vertical jump in 16-22 year old female volleyball players]. [M.Sc thesis]. Çukurova Üniversitesi; 2008. (In Turkish)

8. Muratli S. Antrenman ve Müsabaka [Training and Competition]. Ankara: Gazi Kitabevi; 2005. (In Turkish)

9. Çavdar K. Pliometrik antrenman yapan öğrencilerin sıçrama performanslartnin incelenmesi [Examination of the jump performance of students who applied pliometric training]. [M.Sc thesis]. Marmara Üniversitesi; 2006. (In Turkish)

10.Kurt I. Futbolcularda sekiz haftalı pliometrik antrenmanin anaerobik güç, sürat ve top hızına etkisi [Eight weeks of plyometric training in soccer players on anaerobic power, speed, and ball speed]. [M.Sc thesis]. Sağlık Bilimleri Enstitüsü; 2011. (In Turkish)

11.Karasar N. Bilimsel Araștırma Yöntemi [Scientific Research Method]. Ankara: Nobel Yayınevi; 2014. (In Turkish)
12.Kamar A. Sporda yetenek beceri ve performans testleri [Talent, skill and performance tests in sports]. Ankara: Nobel Yayınevi; 2008. (In Turkish)

13.Orhan S, Pulur A, Gür E. The Effects of the Rope and Weighted Rope Trainings on the Basketball Skills. E-Journal of New World Sciences Academy. 2008;3(4):179-183.

14.Özbek S. 15-17 yaş grubu erkek basketbolcularda hazırlı dönemi ve üst ekstremite kuvvet antrenmanlarinin bazl parametrelere ve sut isabetine etkisi [Effect of preparation period and upper extremity strength training on 15-17 age group male basketball players to some parameters and shot hit performance]. [M.Sc thesis]. Niğde Üniversitesi; 2008. (In Turkish)

15.Kurban M. Futbol antrenmanının 10-13 yaş grubu çocukların teknik gelişimlerine etkisinin araştırılması [The investigation of the effect of football training on the technical development of children at the age group of 10-13]. [M.Sc thesis]. Selçuk Üniversitesi, Sağlık Bilimleri Enstitüsü; 2008. (In Turkish)

16.Ölçücü B. Tenisçilerde pliometrik antrenmanların kol ve bacak kuvveti, servis, forehand, backhand, vuruş süratleri ve vurulan hedefe isabet yüzdelerine etkisinin incelenmesi [Examination of the effect of plyometric training on arm and leg strength, service, forehand, backhand, hit speed and hit percentage to target in tennis]. players]. [ $\mathrm{PhD}$ thesis]. Marmara Üniversitesi, Sağlık Bilimleri Enstitüsü; 2011. (In Turkish)

17.Canikli A. The Effect of Plyometric Exercises on the Forehand and Backhand Stroke Velocities and Hitting Percentage of Male University Student Tennis Players. Australian Journal of Basic and Applied Sciences. 2013;7(11):366-374,.

18.Fletcher IM, Hartwell M. Effect of an 8-Week Combined Weights and Plyometrics Training Program on Golf Drive Performance. The Journal of Strength \& Conditioning Research. 2004;18(1):44-50.

19.Eler S. Hentbole Özgü Kuvvet Antrenmanlarının Genç Erkek Hentbolcülern Bazı Performans Paramet relerinin Üzerine Etkisinin İncelenmesi [The Investigation of the Effect of Handball Specific Strength Training on Some Performance Parameters of Young Male Handball Players.]. Performans Dergisi, 2002; 3(4):25-29. (In Turkish)

20.Ürer S. 15-17 yaș grubu erkek hentbolculara uygulanan üst ve alt ekstremiteye yönelik pliometrik antrenmanların dikey siçrama performansına ve blok üstü şut isabetlilik oranına etkisinin arastırlması [Investigation of the effect of plyometric training on 15 - 17 age group male handball players to upper and lower extremities on the vertical jump performance and upper block shot accuracy rate.]. [M.Sc thesis]. Süleyman Demirel Üniversitesi, Sağlık Bilimleri Enstitüsü; 2013. (In Turkish) 


\section{Information about the authors:}

Demirci D.; http://orcid.org/0000-0003-4672-2378; dnzarda@yahoo.com.tr; Faculty of Health Sciences, Department of Ergoteraphy, İstanbul Bilgi University; İstanbul, Turkey.

Konyali M.; http://orcid.org/0000-0002-7360-0950; mustafa.konyali@hotmail.com; The Institute of Health Sciences, Faculty of Sports Sciences, Kocaeli University; Umuttepe Kampüsü, TR-41380, İzmit, Kocaeli, Turkey.

Akdeniz H. (Corresponding author); http://orcid.org/0000-0001-8171-1821; hakanakdeniz@gmail.com; The Institute of Health Sciences, Department of Physical Education and Sports Teaching, Sakarya University; Sakarya University Esentepe Campus 54187 Serdivan. SAKARYA. Turkey.

Sekban G.; http://orcid.org/0000-0003-1403-5696; gulsah.sekban@kocaeli.edu.tr; Faculty of Sports Sciences, Department of Physical Education and Sports Teaching, Kocaeli University; Umuttepe Kampüsü, TR-41380, İzmit, Kocaeli, Turkey.

Aydin M.; http://orcid.org/0000-0002-4250-4990; mensureaydin@yahoo.com; Faculty of Sports Sciences, Department of Recreation, Kocaeli University; Umuttepe Kampüsü, TR-41380, İzmit, Kocaeli, Turkey.

Cite this article as: Demirci Deniz, Konyali Mustafa, Akdeniz Hakan, Sekban Gülşah, Aydin Mensure. Reviewing the effect of the stretch-shortening cycle workouts on shot hit performance. Physical education of students, 2018;22(1):17-22. doi:10.15561/20755279.2018.0103

The electronic version of this article is the complete one and can be found online at: http://www.sportedu.org.ua/index.php/PES/issue/archive

This is an Open Access article distributed under the terms of the Creative Commons Attribution License, which permits unrestricted use, distribution, and reproduction in any medium, provided the original work is properly cited (http://creativecommons.org/licenses/by/4.0/deed.en).

Received: 27.12.2017

Accepted: 20.01.2018; Published: 27.02.2018 